\title{
Climate Smart Management Options for Improving the Soil Fertility and Farm Productivity in the Middle Hills of Nepal
}

\author{
A. Shrestha*, B. K. Bishwakarma, R. Allen \\ Sustainable Soil Management Programme (SSMP), HELVETAS Swiss Intercooperation Nepal, GPO Box 688, Kathmandu, Nepal \\ *Corresponding Author: alok.shrestha@helvetas.org.np
}

Copyright (C) 2014 Horizon Research Publishing All rights reserved.

\begin{abstract}
Increasing food demand and climate change pose a major challenge to the sustainability of food production systems and safeguarding environmental health. Nepal's economy is primarily reliant on agriculture which is highly sensitive to climate variability. Key concerns in the middle hills of Nepal include declining soil fertility and soil degradation, changing temperature and precipitation patterns, and pest and disease outbreaks, all of which are affecting productivity, prices, incomes, and ultimately livelihoods. This paper describes some simple, farmer-friendly climate smart management options, and analyses their importance, effectiveness and impacts on improving soil fertility and farm productivity. Simple and widely-adopted sustainable soil management and agronomic practices, which are based on efficient use of local resources, include improvement in preparation and management of farmyard manure (FYM) and compost, systematic collection of cattle urine and its use as a base for botanical pesticide and liquid fertilizer, integrating legumes and fodder crops into cropping systems, small-scale collection of rain and run-off water, and improved water use efficiency. These practices have resulted in a statistically significant increase in soil organic matter levels, and have improved soil fertility and structure, workability, and moisture characteristics. Soil organic matter reached a mean of $3.77 \%$ from $3.32 \%$ after adoption of sustainable soil management practices over the period of 1-3 years in 337 farm sites. The nitrogen content of topsoil significantly increased overall $(0.17 \%$ to $0.2 \%)$ and in 3 of 5 time series. Similarly, nitrogen content of improved FYM significantly increased in 3 of 5 series and overall on 350 farmer's fields over a period of 1 to 3 years. $18.6 \mathrm{~kg}$ additional $\mathrm{N}$ was annually gained from a mature cattle with improved farmyard manure management techniques and systematic collection of urine. Additional benefits include enhanced soil carbon storage, and improved crop resilience to changes in weather patterns. Adoption of these practices has contributed to increased productivity, enhanced income, improved food security, and a beneficial impact on the workload of women.
\end{abstract}

Keywords Climate Change, Food Security, Farmyard Manure, Soil Fertility, Sustainable Soil Management, Soil Organic Matter

\section{Introduction}

The most prominent current challenges of the Nepalese agriculture sector are achieving food security and responding to climate change. Food security and sustainable agricultural production, linked to economic growth, livelihood improvement and poverty reduction, are central to the new Agriculture Development Strategy (ADS, 2013). In many areas of the world, where agricultural productivity is already low and means of coping with adverse events are limited, climate change is expected to reduce productivity and make production more erratic (Stern, 2006; FAO, 2010).

Decreased rates of farmyard manure (FYM) application (Shah and Schreier, 1991), poor soil nutrient and water management, inadequate replacement of nutrients removed in harvested materials or loss through erosion, leaching and gaseous emissions, has caused decline in soil organic matter (SOM) levels and soil fertility (Kaini, 2004). Jaishy and Subedi (2000) found SOM levels were low in about two thirds of 9,800 arable topsoils sampled throughout Nepal. Total nitrogen $(\mathrm{N})$ was also low in about half and available phosphorous $(\mathrm{P})$ and potassium $(\mathrm{K})$ in about one third of all samples. Consequently, production of major cereals has been virtually stagnant over the past $15-20$ years and the national average yields of maize, wheat and rice are well below the attainable and experimental yield - indeed, they are well below those reported in neighbouring countries (Kaini, 2004).

Sustainable soil management received strong support at the Rio Summit (1992), in Agenda 21 (UNCED, 1992), UN Framework Convention on Climate Change (UNFCCC, 
1992), and Kyoto Protocol (UNFCCC, 1998). These conventions recognize the importance of protecting and restoring soil resources (Barford., 2001) and of strong links between soil degradation and desertification, loss of biodiversity, threats to food security, increasing poverty, and increased risk of accelerated greenhouse effects and climate change (Komatsuzaki and Ohta, 2007).

Agriculture is both a victim of climate change and a significant cause. Agriculture is directly responsible for $10-12 \%$ of human-generated greenhouse gas (GHG) emissions, excluding emissions resulting from fuel use and fertilizer production. If these, plus forest clearance for farming, are included, agriculture is responsible for a much greater share of global emissions. Increasing food production without further increasing GHG emissions from agriculture makes this challenge all the greater (Pye-Smith, 2013). In this scenario, climate smart agriculture sustainably increases productivity, resilience (adaptation), reduces/removes GHGs (mitigation) and enhances achievement of national food security and development goals (FAO, 2010).

\section{Climate Smart Farm Management Options}

The Swiss-supported Sustainable Soil Management Programme (SSMP)/HELVETAS Swiss Intercooperation is promoting different agricultural practices since 1999 in the mid-hills of Nepal (Figure 1). The major objective of this paper is to assess these agricultural practices from the perspective of climate smartness, and impacts on farm productivity and resilience. It also assesses the effect of these agricultural practices on soil fertility, farm productivity and income, and reducing women's workload.

How climate smart these agricultural practices are, is assessed based on farmers' perceptions and experiences, and by the analyses of the data obtained from on-farm monitoring of nutrient contents of farmyard manure (FYM), topsoil samples, and soil organic carbon (SOC) surveys. On-farm research studies, thesis research, farmer-led experiments, farmer case studies and various impact studies undertaken by SSMP further verified the findings. Related works were reviewed to supplement the findings.

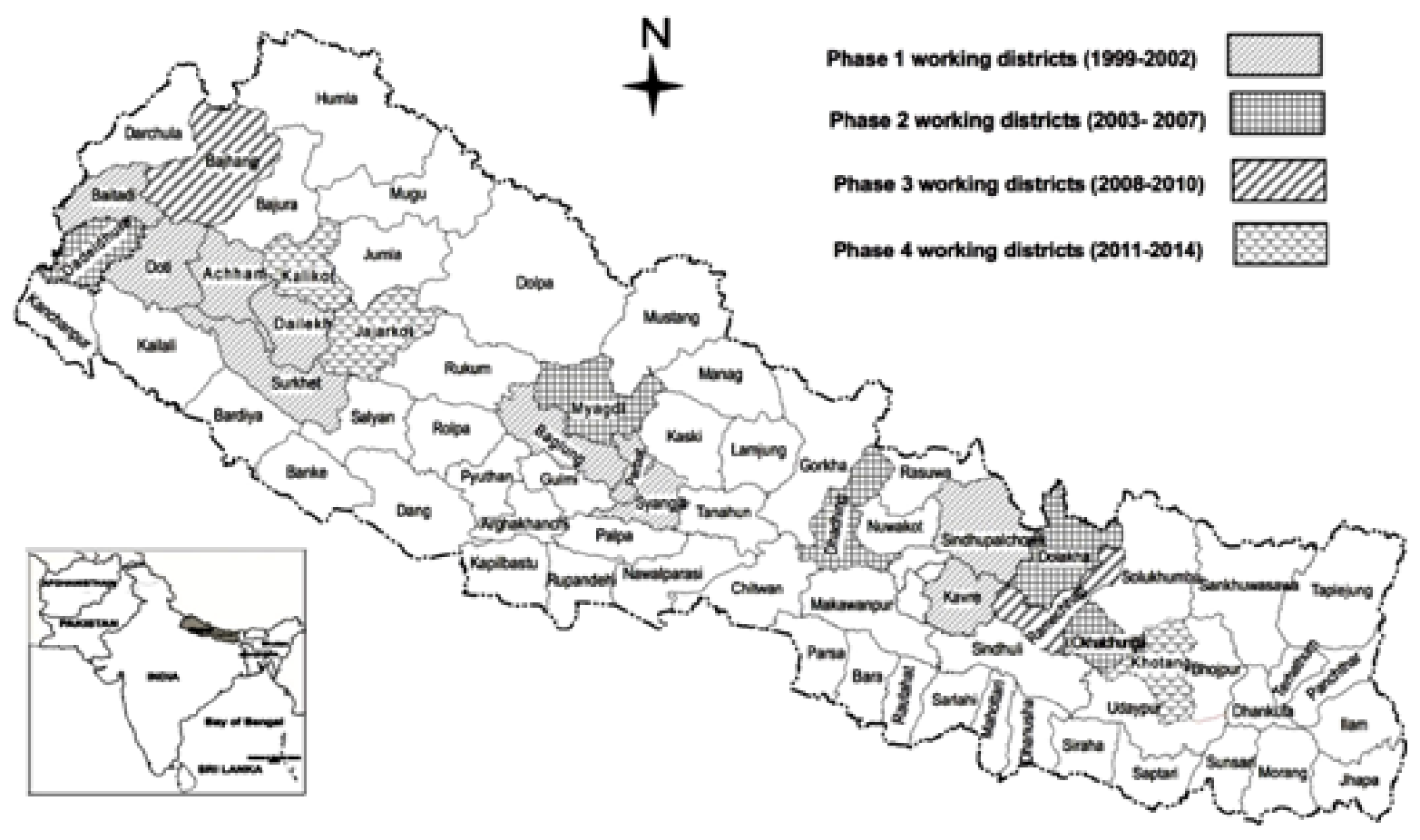

Figure 1. Working Districts of SSMP over its Four Phases 


\section{Soil and Water Management}

\subsection{Improving FYM Quality and Retaining Fertilizer Value of Cattle Urine}

A mature cow/buffalo under normal mid-hill farming condition produces $1,825 \mathrm{~kg}$ fresh dung and 1,460 litres urine per annum (Subedit et al., 2010). The majority of N (up to $97 \%$ ) that is ingested by cattle is excreted in the form of urea and organic $\mathrm{N}$ in urine and faeces (McCrory and Hobbs, 2001). The urea form of $\mathrm{N}$ is highly volatile and losses from urine are faster and higher than from faeces. To maximize $\mathrm{N}$ retention in urine and FYM, it is important to minimize losses from ammonia emission and nitrate leaching during storage and land-spreading (Figure 2).

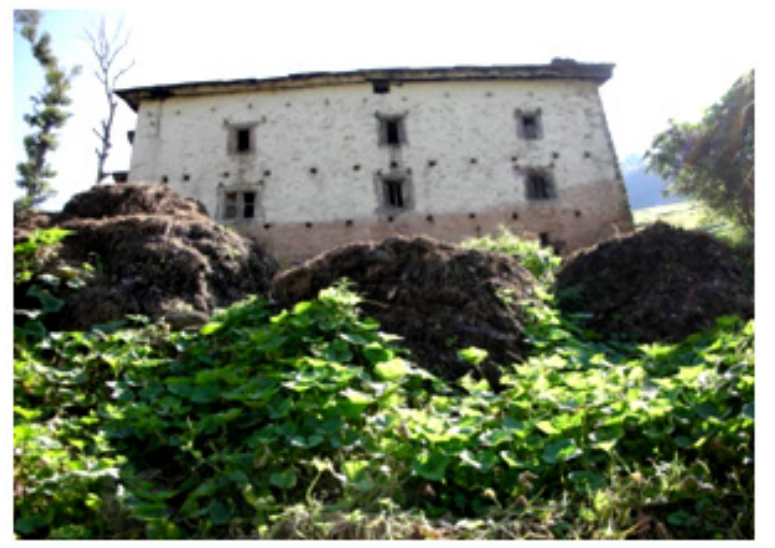

Figure 2. Traditional method of FYM storage: Both FYM and urine isn't systematically managed and used

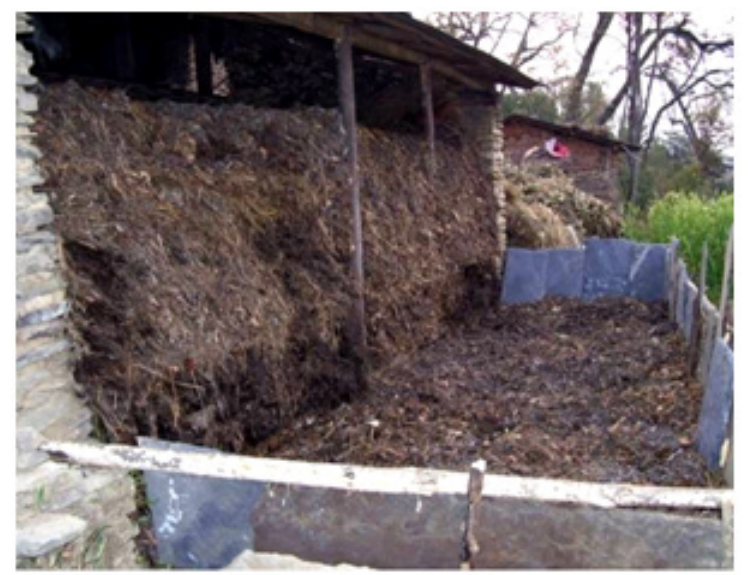

Figure 3a. Improved management practice: FYM heap protected from sun exposure, rainfall and leaching

Improved FYM management techniques involves careful collection, layering and moistening of raw materials, shading the heap from sunlight to minimize $\mathrm{N}$-volatilization, protecting the heap from rainfall to reduce leaching and erosion, no drying of FYM before carrying to the field and immediate mixing into soil, and systematic collection and use of cattle urine as a liquid fertilizer and a base for botanical pesticide (Figures 3a, 3b).

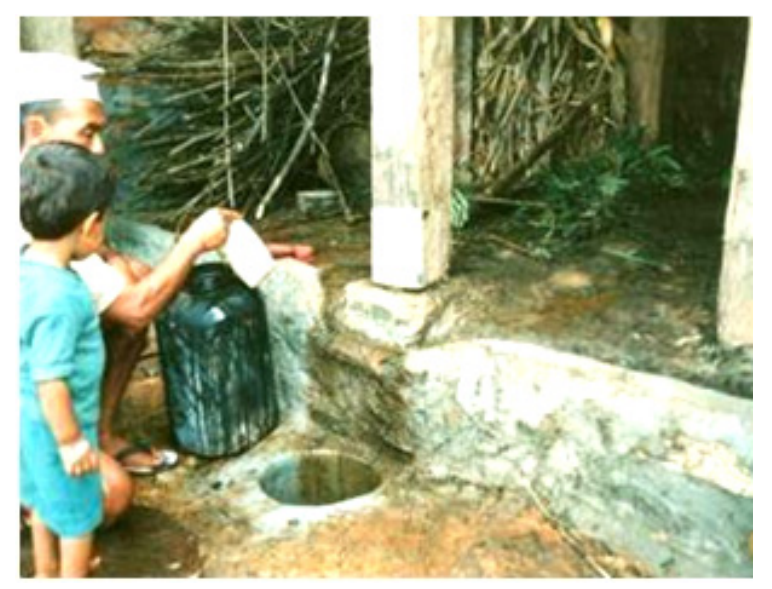

Figure 3b. Systematic collection of cattle urine

\section{Evidence of Improvement from FYM Analysis Results}

Monitoring of N-content in FYM before and after improved practices were introduced to 350 farmers' fields over a period of 1 to 3 years showed a significant but inconsistent improvement in FYM quality. Increase in $\mathrm{N}$-content of FYM after adoption of improved technique was substantial and significant in 3 of 5 series, and overall (Figure 4). The largest increase was for the series starting in 2000 but this may be exaggerated by unduly low pre-adoption values. Adoption effects in the series 2003-2006 were also positive, but were smaller and non-significant. Systematic collection of cattle urine added a significant amount of $\mathrm{N}$ (Table 1).

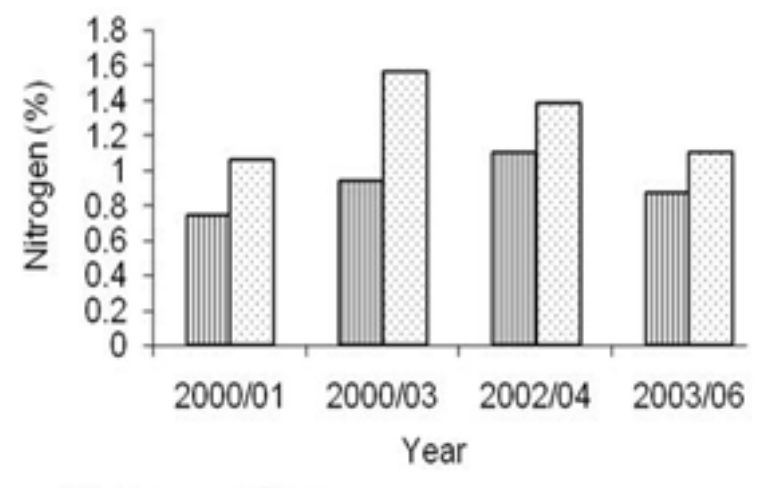

口Before $\square$ After

Figure 4. N-content in FYM before and after adoption of improved management practices 
Table 1. Comparison of $\mathrm{N}$ gain from FYM and cattle urine - with and without improved management techniques

\begin{tabular}{|c|c|c|c|c|c|}
\hline \multicolumn{2}{|c|}{ From FYM, N gain/year } & \multirow{2}{*}{$\begin{array}{c}\begin{array}{c}\text { Additional N } \\
\text { gain/year }\end{array} \\
\begin{array}{c}\text { Managed with } \\
\text { improved } \\
\text { techniques }\end{array}\end{array}$} & \multicolumn{2}{|c|}{ From cattle urine, $\mathrm{N}$ gain/year } & \multirow{2}{*}{$\begin{array}{c}\begin{array}{c}\text { Additional N } \\
\text { gain/year }\end{array} \\
\begin{array}{c}\text { With systematic } \\
\text { collection }\end{array}\end{array}$} \\
\hline $\begin{array}{l}\text { Traditionally } \\
\text { managed }\end{array}$ & $\begin{array}{l}\text { Managed with } \\
\text { improved } \\
\text { techniques }\end{array}$ & & $\begin{array}{c}\text { Without systematic } \\
\text { collection }\end{array}$ & $\begin{array}{l}\text { With systematic } \\
\text { collection }\end{array}$ & \\
\hline $15 \mathrm{~kg}$ & $21 \mathrm{~kg}$ & $6 \mathrm{~kg}$ & $4.2 \mathrm{~kg}$ & $16.8 \mathrm{~kg}$ & $12.6 \mathrm{~kg}$ \\
\hline
\end{tabular}

\subsection{Composting and Crop Residue Management}

Farmers are coached to compost on-farm, using crop residues and vegetation from terrace raisers and other farm areas as livestock bedding which is later incorporated into the FYM or compost pits, and to avoid biomass burning and uprooting of legumes. This has helped to reverse the situation of continued biomass removal from soils and to supplement SOM and plant nutrients.

\subsection{Integrated Plant Nutrient Management System (IPNS)}

IPNS is a holistic approach that integrates all components of soil, plant and nutrient management to achieve higher crop yields and improved soil fertility. The Farmer Field School (FFS) approach was adopted to disseminate the concept of IPNS. Evaluation of 54 FFSs recorded an increase in crop yield of $26 \%$. The results of soil analyses showed an increase in soil fertility, particularly SOM, N, P and K as compared to the base year over a 3 year period (Regmi et al., 2005).

\subsection{Preparation and Use of Botanical Pesticides for Managing Crop Pests}

SSM options for insect pest and disease management include environment-friendly preparation of urine-based botanical pesticide, crop rotation, mixed cropping and measures that are based on local resources, knowledge and skill. Cattle excreta, both urine and FYM, are mixed with milk to control diseases and insects. Different plants, such as Justicia adhatoda, Artemisia vulgaris, Eupatorium adenophorum, Azadirachta indica, Melia azedarach, Tagetes erecta, Urtica dioica, Acorus calamus etc., that possess pesticidal properties are used to prepare botanical pesticides.

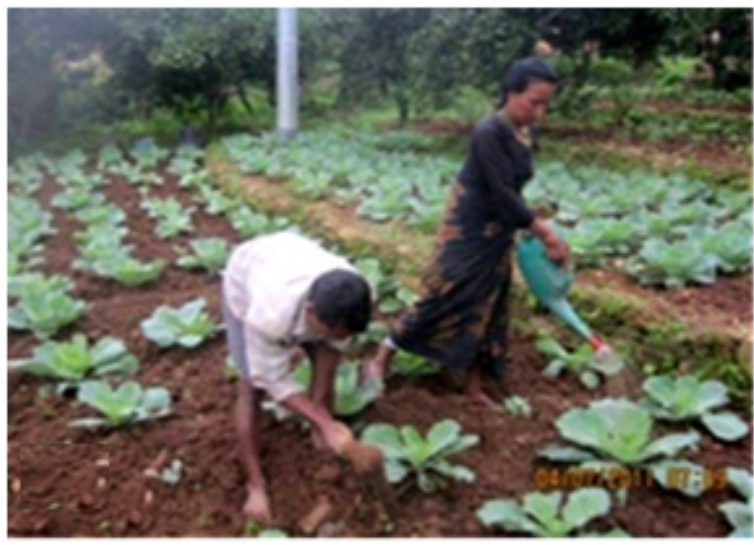

Figure 5a. On-farm research trial on botanical pesticide for managing crop pests

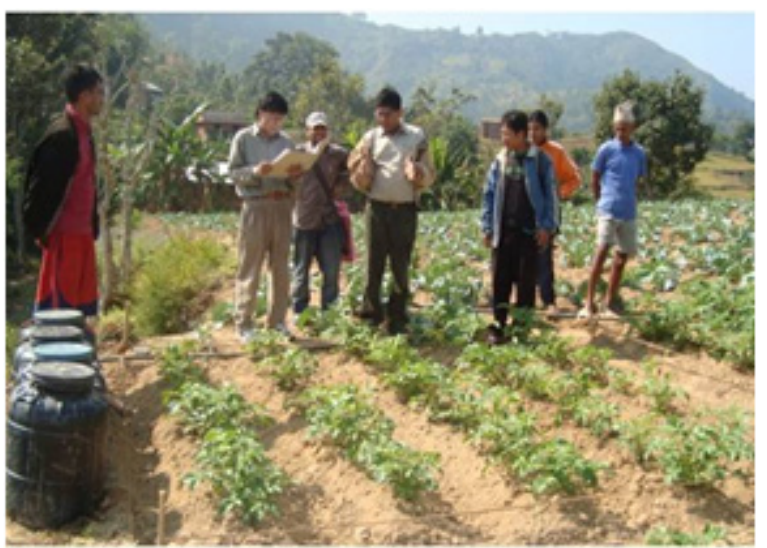

Figure 5b. Farmer-led experiments on botanical pesticides for managing crop pests 
On-farm studies and FLEs (Figure 5a and 5b) proved the effectiveness of bio-pesticides in managing insect pests and diseases (Table 2) with no or minimum damage to the local agro-ecosystem. Bio-pesticides often have an ameliorating effect on the plant-soil environment and beneficial organisms, supplying several essential nutrients, adding organic matter to the soil, and acting as a plant tonic (i.e. cattle urine contains up to $1 \% \mathrm{~N}$ ), thus enhancing crop growth and production.

Table 2. Effectiveness of various botanical pesticides in controlling crop pests: results from farmer-led experiments

\begin{tabular}{lll}
\hline Insect pests or diseases & \multicolumn{1}{c}{ Botanical pesticides } & \multicolumn{1}{c}{ References } \\
\hline $\begin{array}{l}\text { Late blight (tomato, potato), } \\
\text { fruit fly (cucumber), borer } \\
\text { (tomato, brinjal) }\end{array}$ & $\begin{array}{l}\text { Urine-based botanical pesticide: 10 kg each of Artemisia } \\
\text { vulgaris, Justicia adhatoda, Eupatorium adenophorum, Melia } \\
\text { azedarach mixed with 4 litres urine and 4 kg fresh FYM, } \\
\text { fermented for 30 days. }\end{array}$ & Bodhraj Aryal, Farmer, Syangja \\
\hline Caterpillar, aphid & $\begin{array}{l}\text { 1 kg stinging nettle soaked in 8 litres water for 12 hours in summer } \\
\text { and 24 hours in winter, applied within 24 hours of preparation. }\end{array}$ & Keshav Sharma, Farmer, Syangja \\
\hline & $\begin{array}{ll}500 \text { gm stinging nettle soaked in 1 litre water for 24 hours. } \\
\text { Red ant }\end{array}$ & $\begin{array}{l}\text { R.B. Siris and P.B. Naisa, } \\
\text { mixed with 2-3 fitres soap- Baglung }\end{array}$ \\
& $\begin{array}{l}\text { Artemisia vulgaris shoots mixed together, applied after mixing } \\
\text { with water in ratio 1:3-1:5. }\end{array}$ & $\begin{array}{l}\text { Purushottam Lamichhane, } \\
\text { Farmer, Syangja }\end{array}$ \\
\hline Viral diseases & $\begin{array}{l}\text { Cow milk mixed with 4-5 part of water and sprayed at 7-15 days } \\
\text { interval. }\end{array}$ & B.B. Thapa, Farmer, Baglung \\
\hline
\end{tabular}

\subsection{Mulching/Cover Crops}

Farmers and stakeholders in the programme districts perceived mulching as effective in conserving soil moisture in times of drought, and suppressing weed growth. It is most commonly undertaken in seed beds and for crops like potato, cucurbits, ginger and turmeric. Mulching creates a conducive environment for soil microorganisms, adds to the SOM reserve, and often improves quality of produce. It is effective in reducing evapotranspiration and increasing crop growth and yield (Allen et al., 1998).

\subsection{Water Management Strategies}

Farmers in the programme districts have experienced a complete lack of or late occurrence of winter rain, and more intense but less frequent monsoon rain. In one recent survey, $100 \%$ of respondents reported increased drought conditions and $95 \%$ perceived decreased frequency but increased intensity of rainfall. The rainfall records (1999-2008) also verified the farmer's perceptions. Since the mid-hill farmers almost entirely rely on rainfall for their crops, water management strategies are essential to ensure survival of both winter and summer crops in water-deficient periods.

\section{a. Water Collection Pond}

Waste/grey water, surface and roof run-off water can be collected and led to small plastic or earthen ponds at household level, from where water is provided to nearby cash crops during droughty periods (Figure $6 \mathrm{a}, 6 \mathrm{~b}$ ). These water harvesting technologies have been effective in reducing risks associated with water shortage in the mid-hill region.

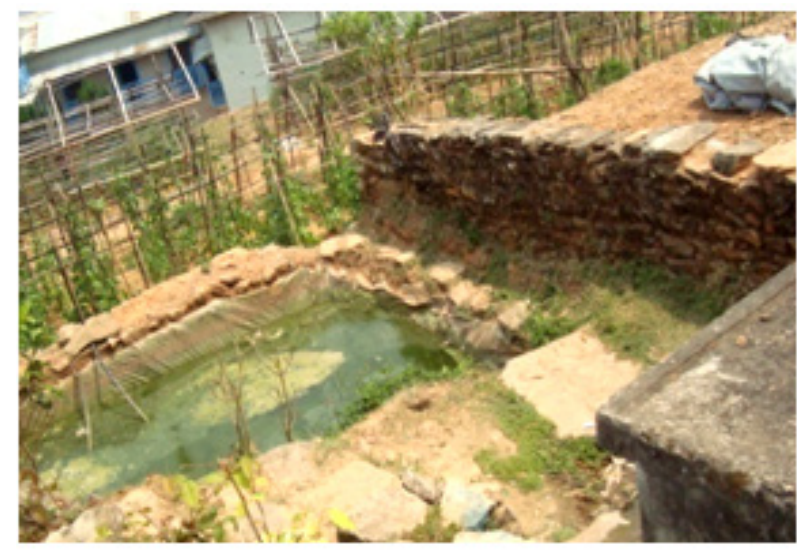

Figure 6a. Waste water from drinking water tap collected in plastic-lined pond to feed plants next to the pond

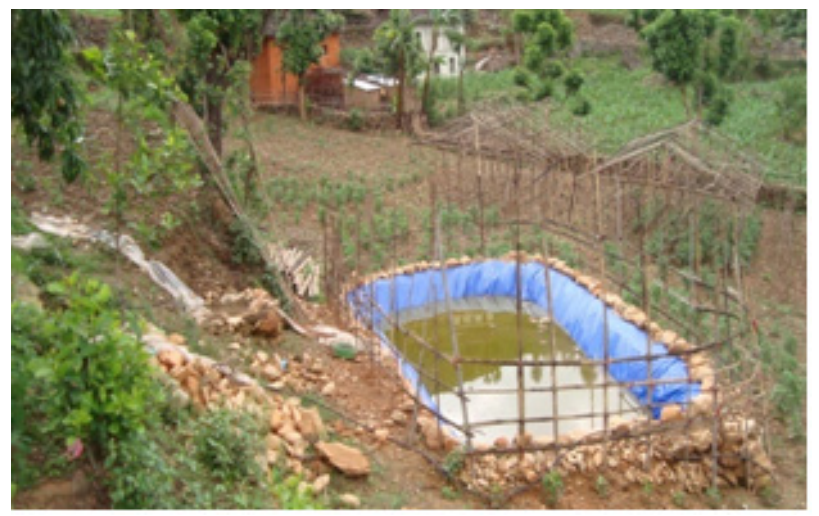

Figure 6b. Silpaulin-lined water harvesting pond that accumulates runoff water channeled via a plastic-lined canal 


\section{b. Irrigation Methods to Improve Water Use Efficiency}

Proper and timely water application method, such as drip irrigation, has been identified as one of the best methods to increase water use efficiency. It requires less water than flooding or sprinkling. Khanal et. al. (2013) reported that drip irrigation, as compared to conventional (bucket) irrigation, resulted in $31 \%$ water saving in cauliflower, and increased cauliflower production/area by $46 \%$ with the same source of water. Moreover, average production per plant increased by $14 \%$, it reduced irrigation labour costs by $40 \%$ and that for weeding and earthing-up by 33\%. Ngigi (2009) also reported that shifting from surface irrigation to drip irrigation increased irrigable area by $200 \%$, improving irrigation efficiency by between 25 and $75 \%$ using the same volume of water. Regmi et al. (2009) also reported that the local communities in Kaski district of Nepal found drip irrigation saved water, improved yields and reducinged losses during droughts, thereby combatting water shortage. Similarly, sprinkling on coffee plants induced flowering when the rain failed in the flowering season, and sprinkling warm water on plants in coffee nurseries maintained heat.

\section{Crop Management}

\subsection{Inclusion of Legumes into Cropping System}

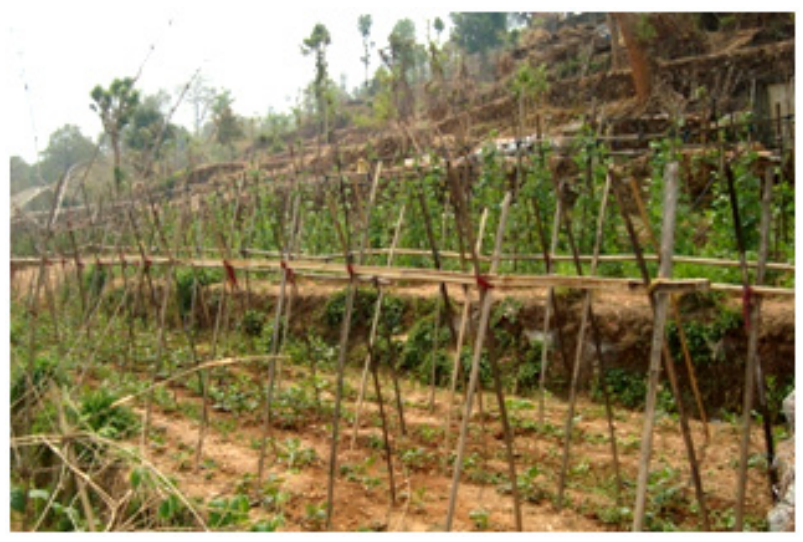

Figure 7. Integrating cowpea into the cropping pattern

Legumes improve $\mathrm{N}$ levels in cultivated soil through biological $\mathrm{N}$ fixation and scavenging residual soil $\mathrm{N}$, making it available for subsequent crops. Legumes also supply organic matter to soil, suppressing weeds and breaking pest cycles (Peet, 1996; Magdoff, 1998). Growing legumes along with cereals leads to nutrient recycling. Legumes are prolific leaf shedders, and act as a natural manure to conserve soil moisture and maintain soil fertility (Tiwari, 2001). SSMP strongly encourages inclusion of legumes into the cropping system as a sole crop (Figure 7), as a mixed, relay or catch crop, as a cover and green manuring crop, in mixed cropping systems and as forage crops to improve livestock nutrition. It also provides additional cash income for farmers, and compensates the farmers in case the major crop fails.

\subsection{Growing Drought Tolerant Crops/Cultivars}

Some crops and cultivars can withstand drought conditions better than others, and thus reduce the risk of total crop failure. Grain legumes, like horse gram and rice gram can better withstand drought condition relative to other grams and legumes. Some cultivars of rice available in Nepal, such as Sukkha Dhan 1, Sukkha Dhan 2, Sukkha Dhan 3, Radha 4, Radha 7, Radha 11, Bindeshwari, Janaki, Makawanpur 1 are recommended for rainfed conditions, and the wheat variety WK 1204 and maize variety Deuti are reported to be relatively drought tolerant. The nature of such crops and varieties indicates that these are not only important for the food security of people living in harsh and difficult terrain but also for those living in other areas which are prone to the adverse effects of climate change.

\subsection{System of Rice Intensification (SRI)}

One aspect of SRI is the alternate wetting and drying of soil during the rice cropping season rather than continuous flooding. Cooper et al. (2013) reported that flooded rice consumes nearly $40 \%$ of all irrigation water. It also produces about $10 \%$ of all methane produced by human activities; methane is 25 times more potent than carbon dioxide as a GHG. Allowing the soil to dry out intermittently lets air in, preventing build-up of anaerobic bacteria responsible for methane production. SRI has shown reductions in methane emissions by up to $50 \%$, and reductions in water use by up to $40 \%$. SRI brings immediate benefits to the farmers in terms of increased yield, while building long-term resilience by reducing the amount of water use, reducing emissions of GHG, and sequestering carbon in the soil.

\section{Agro-forestry}

\subsection{Fodder and Forage Crops}

Fodder and forage crops provide livestock with improved feed, re-cyclable nutrients, and builds resilience of local agro-ecosystems. SSMP promotes planting of both fodder and forage crops on terrace risers or ridges, wasteland around the farm (which often accounts for $25 \%$ of farm areas), and for inclusion in crop rotations (Figure 8). It also encourages stall feeding and reduces women's workload, significantly decreasing time and energy in collecting fodder. It also reduces evaporation and provides biomass for fuel, binds soil, thereby protecting land from erosion, and acts as a home for beneficial insects and birds. 


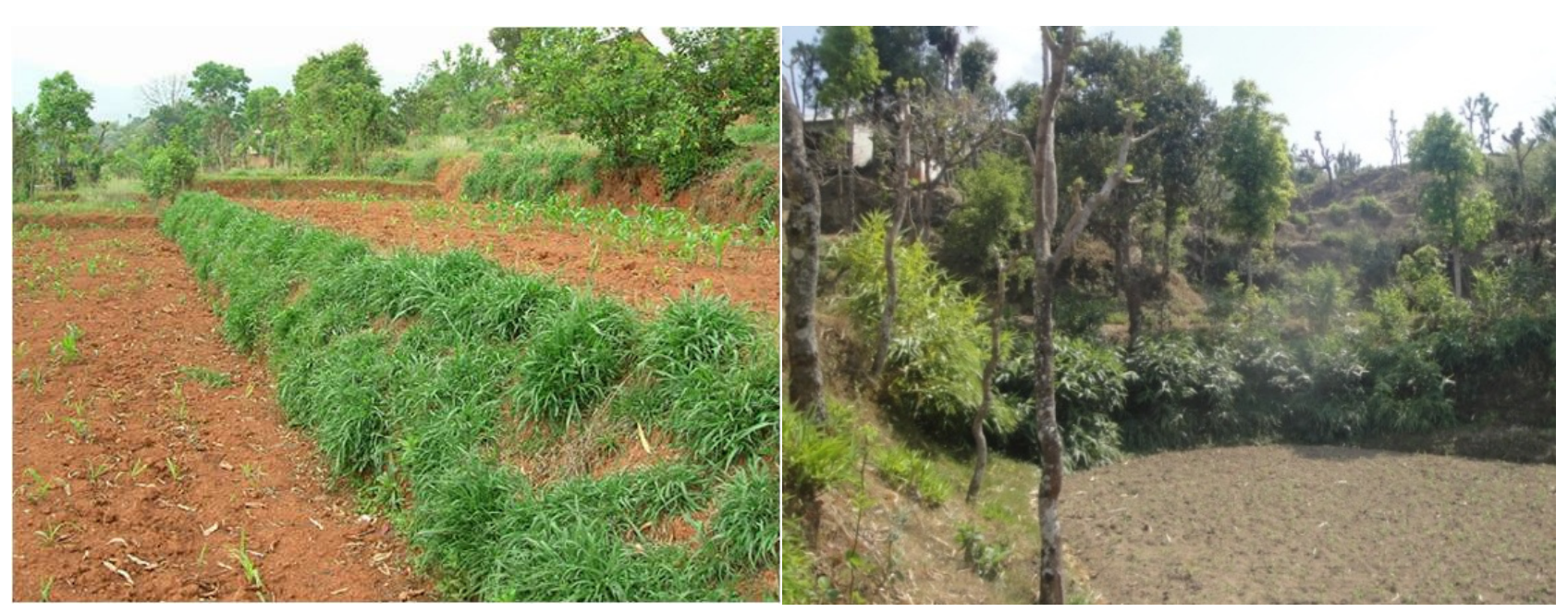

Figure 8. Forage/fodder production on terrace risers

Cooper et. al.(2013) also reported that fodder and forage improves soil structure and fertility, thus rain soaks into the soil more readily resulting in water table replenishment (especially in desert and dry areas), thereby making water more accessible to plants, livestock and people. Other advantages include increasing the resilience of farming systems to extreme weather events, diversifying sources of food and income, protecting land and water resources, and sequestering carbon in the soil, root and biomass. Regmi et al. (2009) also found that the farmers were able to cope with the invasion of new grass species by growing fodder and forage, which also improved resilience to climatic stresses like drought and flooding Effect of Climate Smart Practices on Soil Fertility

337 farm sites were monitored before and after SSM practices in terms of SOM and topsoil nutrient contents. An increase in SOM was reported in each of the time series (Figure 9).

Wilcoxon comparisons showed significant increases in soil $\mathrm{N}$ overall and in 3 of 5 individual time series (Table 3 ). The topsoil $\mathrm{N}$ content increased in parallel with SOM, but the effect was slightly less consistent, with significant increases recorded overall and in 3 of 5 time series. The effect on available $\mathrm{P}$ in topsoil was inconsistent, with significant increases overall and in 2 series, and insignificant decreases in the other 2 series.

There were significant decreases in soil $\mathrm{K}$ overall and in 3 series, with a small but insignificant increase in another one. The decrease may be exaggerated by inflated pre-adoption values. However, a decrease was also reported in other series, suggesting that the effect is real. Soil $\mathrm{pH}$ values varied little, with insignificant effects from improved practices.

Another study undertaken in four districts during 2009-2010 revealed that the effect of soil management on SOC were most marked in the $0-15 \mathrm{~cm}$ horizon, but continued to be significant well into the subsoil. SOC in topsoils treated with SSM practices was similar to those under forest, although the forest subsoil had substantially but insignificantly higher levels of SOC. SOC levels were significantly higher in the treated soils than in the non-treated topsoil, and substantial differences continued into the subsoil but were less significant. $\mathrm{N}$ is the major nutrient associated with SOM and its pattern was similar to that of SOC, with significantly higher content in the treated soils, particularly in the topsoil (Dahal and Bajracharya, 2012).

Since SOC levels are very sensitive to soil management practices, SSM technologies clearly and significantly contribute to increased SOC. Several long-term studies have also shown the benefits of manuring, adequate fertilization and crop rotation in maintaining productivity and in increasing carbon input into the soil (Mitchell et al., 1996; Reeves, 1997). Two randomized long-term trials comparing organic and conventional farming practices for over 20 years showed remarkable higher carbon contents in organic plots. Evidence from other research (eg. Grandy et al., 2007; Hepperly et al., 2006) also reveal that climate smart management options as described in this paper can sequester more carbon into the soil. 


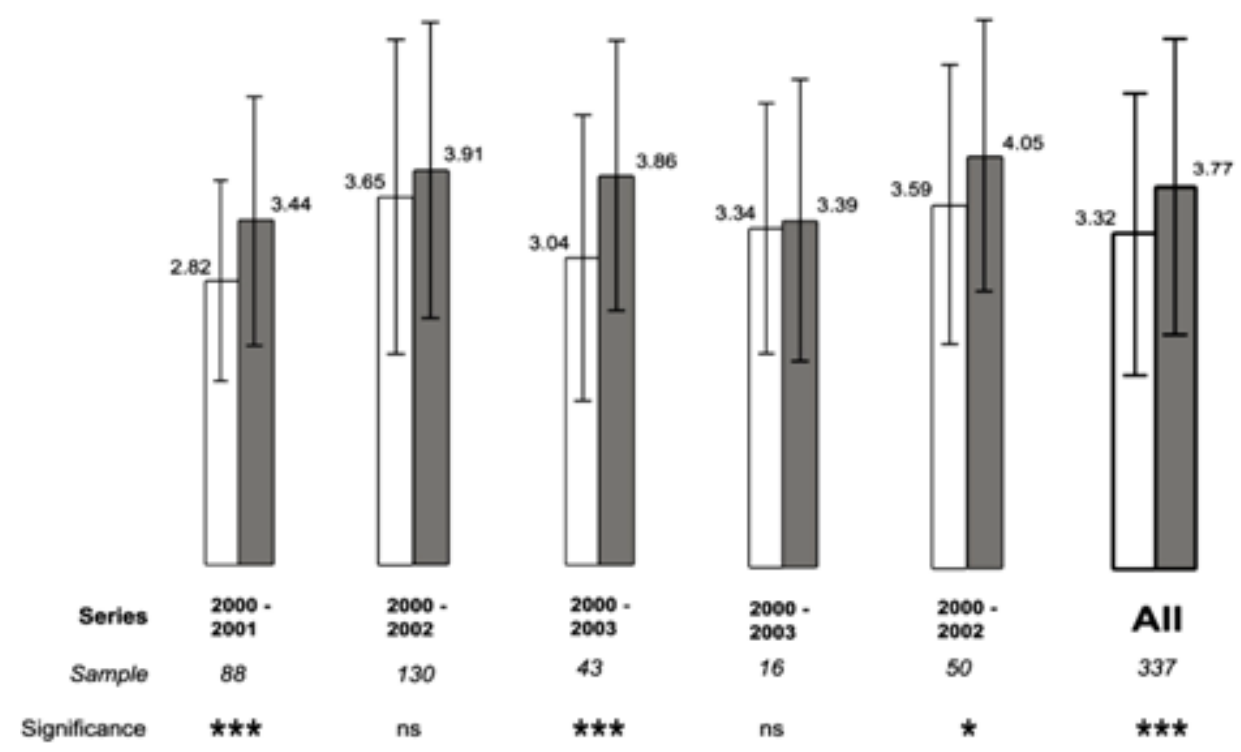

Figure 9. Effects of climate smart practices on soil organic carbon in monitored soils

Table 3. Effect of SSM technologies on nutrient fertility attributes in monitored topsoils

\begin{tabular}{|c|c|c|c|c|c|c|c|c|c|c|c|c|c|c|}
\hline \multirow{2}{*}{ Series } & \multirow{2}{*}{$\begin{array}{c}\text { Duration } \\
\text { (year) }\end{array}$} & \multirow{2}{*}{$\mathrm{n}$} & \multicolumn{3}{|c|}{$\begin{array}{c}\text { Total N } \\
(\%)\end{array}$} & \multicolumn{3}{|c|}{$\begin{array}{c}\text { Available P } \\
(\mathrm{mg} / \mathrm{kg})\end{array}$} & \multicolumn{3}{|c|}{$\begin{array}{c}\text { Available K } \\
(\mathrm{mg} / \mathrm{kg})\end{array}$} & \multicolumn{3}{|c|}{ Soil pH } \\
\hline & & & Start mean & $\begin{array}{c}\text { End } \\
\text { mean }\end{array}$ & $\begin{array}{c}\text { Increase \% } \\
\& \\
\text { significance }\end{array}$ & Start mean & End mean & $\begin{array}{c}\text { Increase \% } \\
\& \\
\text { significance }\end{array}$ & Start mean & $\begin{array}{c}\text { End } \\
\text { mean }\end{array}$ & $\begin{array}{c}\text { Increase \% \& } \\
\text { significance }\end{array}$ & $\begin{array}{l}\text { Start } \\
\text { mean }\end{array}$ & $\begin{array}{l}\text { End } \\
\text { mean }\end{array}$ & $\begin{array}{c}\text { Increase \% \& } \\
\text { significance }\end{array}$ \\
\hline $\begin{array}{c}2000-2 \\
001 \\
\end{array}$ & 1 & 88 & 0.14 & 0.18 & $25 * * *$ & 26.21 & 39.02 & $49 * * *$ & 481 & 388 & $-19 * *$ & 5.99 & 5.94 & $-1 \mathrm{~ns}$ \\
\hline $\begin{array}{c}2000-2 \\
002 \\
\end{array}$ & 2 & 130 & 0.19 & 0.2 & $4 \mathrm{~ns}$ & 35.37 & 36.21 & $2 \mathrm{~ns}$ & 472 & 501 & $6 \mathrm{~ns}$ & 5.94 & 6.04 & $2 *$ \\
\hline $\begin{array}{c}000-20 \\
03 \\
\end{array}$ & 3 & 43 & 0.16 & 0.23 & $43 *$ & 21.59 & 17.64 & $-18 n s$ & 468 & 373 & $-20 *$ & 5.41 & 5.94 & $10 * * *$ \\
\hline $\begin{array}{c}2002-2 \\
005 \\
\end{array}$ & 3 & 16 & 0.18 & 0.17 & $-6^{*}$ & 26.88 & 24.46 & $-9 n s$ & 363 & 309 & $-15 n s$ & 5.87 & 5.74 & $-2 n s$ \\
\hline $\begin{array}{c}2003-2 \\
006 \\
\end{array}$ & 3 & 50 & 0.18 & 0.2 & $12 * *$ & 28.73 & 37.51 & $31 * *$ & 334 & 235 & $-30 * *$ & 5.77 & 5.67 & $-2 n s$ \\
\hline All & $1-3$ & 327 & 0.17 & 0.2 & $16^{* * *}$ & 29.77 & 34.16 & $15^{*}$ & 448 & 404 & $-10^{*}$ & 5.85 & 5.93 & $1 \mathrm{~ns}$ \\
\hline
\end{tabular}

Significance of difference between pre- and post-SSM means $\left({ }^{* * *} \mathrm{p}<0.001,{ }^{* *} \mathrm{p}<0.01,{ }^{*} \mathrm{p}<0.05\right.$, ns $\left.\mathrm{p}>0.05\right)$. 
Climate smart agricultural practices include the application of organic manure, biological pest control, legume integration, mulching, and crop rotation, make the best use of local resources, and are environmentally sound (Muller-Lindenlauf, 2009). These practices also assist in reducing the emissions from mineral fertilizer production, which are reported to contribute $1 \%$ of global anthropogenic greenhouse gas emissions (FAOSTAT; EFMA; Williams, 2006).

\section{Climate Smart Practices: Improving Farm Productivity and Income}

The practices described in this paper contribute to increased production of cereals, seasonal and off-season vegetables and cash crops, thus increasing income and food security. Many farmers who have been adopting such practices over the past 5 years have doubled the yields of cereals, vegetables and cash crops (SSMP, 2010b). Adoption of SSM practices has resulted in better soil aggregation and easier tillage, decreased crusting and clodding, and increased moisture availability. On average, adoption of such practices has increased crop yields by up to $30 \%$ as compared to traditional practices. Some farmers mentioned improved crop yield in dry years.

A number of factors are responsible for increased crop yield; improved SOM levels and soil structure, and increased nutrient supply from organic sources. The increase in SOM improves crop yield and conserves water. Potential crop yield increases of about $12 \%$ for every $1 \%$ of organic matter have been reported (Magdoff, 1998). Quiroga et al. (2006) found that crop yields in similarly textured soils depend on total SOM content and an increase in SOM significantly increases nitrate availability.

Climate smart management options, such as legume integration, FYM improvement, systematic collection \&and use of cattle urine, combined with integrated livestock production increases the SOM, thereby increasing the water capturing capacity of the agricultural system and lowering the risk of soil erosion. Hence, the risk, of yield losses by extreme weather events is also lowered (Lotter, 2003). Since these practices do not rely on external inputs, it increases the agricultural productivity and livelihoods of rural communities who have no or little access to inputs, It can promote food availability and increase the income of small scale farmers (Zundel et al., 2007; FAO 2009). A growing demand for organically produced food can offer access to premium prices and hence higher income (Willer et al., 2009).Impact of Climate Smart Options on Women'S Workload

Increasing outmigration of males from rural areas in search of gainful off-farm employment has resulted in an increased workload for women, the feminization of the agriculture sector. Agricultural technologies/practices need therefore to pay due consideration to this major social change.

Initially, adoption of improved FYM management practices and cattle urine collection, demand some additional labour, but it is observed that in the long run, it significantly reduces workload in terms of collecting materials, cleaning cattle-sheds, carrying manure to field (well-prepared manure is lighter), and land preparation. Field studies indicated that after adoption of such improved practices, often with little capital outlay, men have started helping with work, such as FYM management, urine collection and bio-pesticide spraying, tasks previously considered as women's responsibility, especially in remote rural areas. This uptake by men is encouraged by improving the cattle-shed design for easier urine collection (through better drainage and piping the urine to the pit or tank), and the use of a manuring fork to simplify collection. Other practices that have reduced women's workload include: promotion of on-farm fodder and forage, integrating legumes into the cropping system, water collection and conservation strategies, and composting (Bishwakarma, 2013).

\section{Mainstreaming Climate Smart Practices in Governmental Policies and Programmes}

Recent policies and programmes of the Government of Nepal in regard to adoption and promotion of climate smart agricultural practices are promising.

1. Recognition and internalization of climate smart practices as sustainable soil and crop management strategies by the Ministry of Agriculture Development and its reflection in policy and programmes: support is now provided to farmers in 33 districts outside the current SSMP-working districts for promotion of improved cattle-sheds and FYM management.

2. Establishment of Agriculture, Forestry and Environment Committees (AFECs) at the village level and mobilization of locally-developed Experienced Leader Farmers (ELFs) as extension agents, all of whom have been trained in these climate smart technologies.

3. Mandate from the Ministry of Federal Affairs and Local Development to allocate at least $15 \%$ of the VDC grants for sustainable agricultural technologies - the VDC is the lowest rung of the administrative structure in Nepal.

4. Increased focus on promotion of organic products.

5. Recognition of organic manure as a fertilizer (Fertilizer Act 2001), and provision of subsidies to establish organic fertilizer factories, and support reduced prices of bio-fertilizers.

6. Climate Change Policy (2011) and the framework on National Adaptation Programme of Action (NAPA) and Local Adaptation Plan of Action (LAPA) have also focused on formulating local adaptation plans for the agriculture sector.

\section{Support Needed for Farmers}

In the context of a global and competitive market 
economy, increasing pressure on agricultural production, ever-increasing outmigration of youth, and food security and sustainable land management, Nepalese farmers need political, economic and social commitment and incentives to adopt climate smart and sustainable soil management strategies. Smallholder farmers require direct incentives to encourage the adoption of climate smart management options and income-generating production technologies.

Supporting cattle-shed improvement is a good strategy to substitute chemical fertilizer and encourage farmers to best use locally available resources. Return on investment for a simple redesigned-cattle-shed, costing NRs. 7,000-12,000 (approx. \$70-120), is covered within a short period as an additional $19 \mathrm{~kg} \mathrm{~N}$ derives from a single cattle each year thus such investment is both environmentally and financially sound.

\section{Conclusions}

The agricultural sector in Nepal must become climate smart to successfully tackle the current challenges of food security deficits and climate change. The practices described here are climate smart options, which increase farm productivity, strengthen farmer's resilience, reduce GHG emissions and increase carbon sequestration. They strengthen food security and deliver both financial and environmental benefits. Practices that do not involve imported inputs or cash outlays and concerned with improving FYM quality offer a bottom-up, boot-strapping way to reverse the downward spiral of declining soil fertility. Socio-political commitment, and policy and programme initiatives are therefore required to directly support the smallholder farmers to adopt such agricultural options on a wider scale. If agriculture is to be part of the solution to climate change, and at the same time, continue to contribute to food security and poverty alleviation, there will be a need for a significant increase in investment in climate-smart agricultural policies and practices. Since failure in making this shift would put future food security at risk, greater emphasis needs to be placed on agriculture in climate change policy discussions. This will ensure that agriculture fully contributes to future adaptation and mitigation efforts without undermining food production and the fight against poverty.

\section{Acknowledgement}

Funding for SSMP, from which study findings were generated, is provided by the Swiss Agency for Development and Cooperation (SDC). The authors would like to thank SSMP colleagues and HELVETAS Swiss Intercooperation Nepal for support in attending the ICOAF 2014, Sri Lanka. This study has only been possible with the understanding, support and cooperation of farmers, extension agents, and local committee members in the project districts; the authors are much obliged to them.

\section{REFERENCES}

[1] ADS (2013). Agricultural Development Strategy, Final Report. Government of Nepal.

[2] Allen, R.G., Pereira,L.S., Raes,D. and Smith, M. (1998).Crop evapotranspiration, Guidelines for computing crop water requirements. Irrig.\& Drain. Paper, No. 56, FAO, Rome, Italy.

[3] Barford, C. C., Wofsy S. C., Goulden M. L., Munger, J. W., Pyle, E. H., Urbanski, S. P., Hutyra, L., Saleska, S. R., Fitzjarrald, D. \& Moore, K. (2001). Factors controlling longand short-term sequestration of atmospheric $\mathrm{CO} 2$ in a mid-latitude forest. Science, 294 (5547), 1688-1691.

[4] Bishwakarma, B. K. (2013).A brief assessment of possible agricultural labour-saving options. Sustainable Soil Management Programme, HELVETAS Swiss Intercooperation Nepal.

[5] CBS (2008).Statistical Year Book of Nepal. Central Bureau of Statistics, Kathmandu, Nepal.

[6] Cooper, P. J. M., Cappiello, S., Vermeulen, S. J., Campbell, B. M., Zougmoré, R. and Kinyangi, J. (2013).Large-scale implementation of adaptation and mitigation actions in agriculture, Working Paper No. 50.

[7] Dahal, N., Bajracharya, R. M. (2012).Effects of Sustainable Soil Management Practices on Distribution of Soil Organic Carbon in Upland Agricultural Soils of the Nepal Mid-hills. Nepal Journal of Science and Technology, 13, 133-141.

[8] EFMA (European Fertilizer Manufactures Association). Understanding Nitrogen and its Uuse in Aagriculture, Bruessels.

[9] FAO. (2009). Increasing Incomes and Food Security of Small Farmers in West and Central Africa through Exports of Organic and Fair-trade Tropical Products. Mango, Pineapple, Cocoa. Trade and Markets Division of the Food and Agriculture Organisation of the United Nations. GCP/RAF/404/GER. Rome.

[10] FAO (2010). Climate-smart Agriculture: Policies, practices and financing for food security, adaptation and mitigation. Document prepared as a technical input for the Hague Conference on Agriculture, Food Security and Climate Change 2010.

[11] Grandy, A. S. and Robertson, G. P. (2007). Land-use Intensity Effects on Soil Organic Carbon Accumulation Rates and Mechanism. Ecosystems 10: 59-71.

[12] Hepperly, P., Douds, Jr., and Seidel, R. (2006). The Rodale Farming System Trail 1981-2005 : Long Term Analysis of Organic and Conventional Maize and Soybean Cropping Systems. In: Long-tern Field Experiments in Organic Farming. Raupp, J., Pekrun, C., Oltmanns, M. and Kopke, U. (eds.). pp 15-32. International Society of Organic Agriculture Research (ISOFAR), Bonn.

[13] Jaishy, S. N., Subedi, T. B. (2000). Procedures for Soil 
Sampling and Analysis. Soil Testing and Service Section, Lalitpur, Nepal.

[14] Kaini, B. R. (2004).Increasing crops production in Nepal. In: Sherchan, D. P., Adhikari, K., Batsa, B. K. and Sharma, D. (eds.) Proceedings of 24th National Summer Crops Research Workshop on Maize Research and Production in Nepal 2004. National Maize Research Programme and Nepal Agriculture Research Council, Kathmandu, Nepal. 15-19.

[15] Khanal, U., Thapa, K. and Thapa, K. B. (2013). Climate change adaptation practices against water scarcity in High Mountain areas. In: Udas, R., Thapa, K. and Lamsal, K. (eds.) NGO Network Bulletin on Climate Change: Strengthening governance for local adaptation, Issue 5, September 2013.

[16] Komatsuzaki, M., Ohta, H. (2007). Soil management practices for sustainable agro-ecosystems. SustainSci, 2, $103-120$

[17] Lotter, D., Seidel, R. and Liebhardt, W. (2003). The Performance of Organic and Conventional Cropping Systems in an Extreme Climate Year. American Journal of Alternative Agriculture 18: 146-154.

[18] Magdoff, F. (1998).Building soils for better crops. University of Nebraska Press, Lincoln, Nebraska.

[19] McCrory, D. F., Hobbs, P. J. (2001). Additives to reduced ammonia and odor emissions from livestock wastes: A review. J Environ Qual, 30, 345-355.

[20] Mitchell, C. C., Arriaga, F. J., Entry, J. A., Novak, J. L., Goodman, W. R., Reeves, D. W., Rungen, M. W. and Traxler, G. J. (1996). The old rotation, 1896-1996: 100 years of sustainable cropping research. Alabama Agricultural Experiment Station Bulletin, Auburn University, Alabama.

[21] Muller-Lindenlauf, M. (2009). Organic Agriculture and Carbon Sequestration: Possibilities and Constraints for the Consideration of Organic Agriculture within Carbon Accounting Systems. Natural Resources Management and Environment Department, FAO, Rome.

[22] Ngigi, S.N. (2009). Climate change adaptation strategies: Water resources management options for smallholder farming systems in Sub-Saharan Africa. The MDG Centre for East and Southern Africa, The Earth Institute at Columbia University, New York. 189.

[23] Peet, M. (1996).Soil management. In: Peet M (ed.) Sustainable practices for vegetable production in the south. Pullins, Newburyport, Massachusetts.

[24] Pye-Smith, Charlie. (2013). Farming's climate smart future: Placing agriculture at the heart of climate-change policy. Technical Centre for Agricultural and Rural Cooperation AVP-EU (CTA), The Netherlands and CGIAR Research Program on Climate Change, Agriculture and Food Security (CCAFS), University of Copenhagen,, Denmark.

[25] Quiroga, A., Funaro, D., Noellemeyer, E., Peinemann, N. (2006).Barley yield response to soil organic matter and texture in the Pampas of Argentina. Soil Till Res, 90, 63-68.

[26] Reeves, D. W. (1997). The role of soil organic matter in maintaining soil quality in continuous cropping systems. Soil Till Res, 43(1), 131-167.

[27] Regmi, B. D., Poudel, C., Tripathi, B. P., Schulz, S., Dhital, B. K. (2005). Managing soil fertility problems of marginal agricultural lands through integrated plant nutrient systems: Experiences from the hills of Nepal. In: Andersen, P., Tuladhar, J.K., Karki,K.B. and Maskey, S. L. (eds.) Micronutrients in South and Southeast Asia, Proceedings of International Workshop2004. Kathmandu, Nepal. 109-119.

[28] Regmi, B. R., Thapa, L., Suwal, R., Khadka, S., Sharma, G. B. and Tamang, B. B. (2009). Agro-biodiversity Management : An Opportunity for Mainstreaming Community-based Adaptation to Climate Change. Journal of Forest and Livelihood 8(1). ForestAction Nepal.

[29] Shah, P. B., Schreier, H. (1991).Nutrient deficiency and soil fertility issues. In: Shah, P. B., Schreier, H., Brown, S. J.and Riley, K.W. (eds). Soil fertility and erosion issues in the Middle Mountains of Nepal. International Development Research Centre, Ottawa.

[30] SSMP (2010a).Climate Change in the midhills of Nepal- fact or fiction? from a farmer's perspective. Sustainable Soil Management Programme, HELVETAS Swiss Intercooperation Nepal, Document No. 162.

[31] SSMP (2010b).Farmer Profile from the Mid-Hills of Nepal: A collection of individual stories from partners of the Sustainable Soil Management Programme, Vol.2, June 2010, Sustainable Soil Management Programme, Helvetas Swiss Intercooperation Nepal,Document No 161.

[32] Stern, N. (2006).Stern Review on The Economics of Climate Change. HM Treasury, London.

[33] Subedi, K. D. (1993).Search of indigenous green manuring species in the western hills of Nepal. LARC review paper No. $93 / 2$.

[34] Tiwari, T. P. (2001). Participatory crop improvement for maize/ millet intercropping in the middle hills of Nepal. Thesis (M. Sc.) - University of Wales. School of Agricultural and Forest Sciences, Bagnor, UK.

[35] UNCED (1992).Agenda 21: Programme of action for sustainable development. The Rio declaration on environment and development, statement of principles. Final text of agreement negotiated by governments at the United Nations Conference on Environment and Development (UNCED), Rio de Janeiro, Brazil, UNDP, New York. 3-14.

[36] UNFCCC (1992). United Nations Framework Convention on Climate Change. UNFCCC, Bonn, Germany.

[37] UNFCCC (1998). Kyoto Protocol to the United Nations Framework Convention on Climate Change. Retrieved from http://unfecc.int/resource/docs/convkp/kpeng.pdf.

[38] Willer, H. and Kilcher, L. (eds.) (2009). The World of Organic Agriculture. Statistics and Emerging Trends 2009. IFOAM, Bonn; FiBL, Frick; ITC, Geneva.

[39] Williams, A.G., Audsley, E. and Sandars, D.L. (2006). Determining the Environmental Burdens and Resource Use in the Production of Agricultural and Horticultural Commodities. Main Report. Defra Research Project IS0205. Bedford: Cranfield University and Defra. Available on and www.defra.gov.uk.

[40] Zundel, Ch. and Kilcher, L (2007). Organic Agriculture and Food Availability. International Conference on Organic Agriculture and Food Security, 3-5 May 2007, FAO, Italy. 